\title{
Airway response of asthmatic subjects to inhaled allergen after exposure to pollutants
}

\author{
C Rusznak, J L Devalia, R J Davies
}

\begin{abstract}
Background - Recent studies have suggested that air pollutants resulting from vehicle exhaust emissions and burning of fossil fuels, either in combination or individually, may enhance the airway response of asthmatic subjects to inhaled allergen. It was hypothesised that the airway response to inhaled allergen after exposure to a combination of $400 \mathrm{ppb}$ nitrogen dioxide $\left(\mathrm{NO}_{2}\right)$ and $200 \mathrm{ppb}$ sulphur dioxide $\left(\mathrm{SO}_{2}\right)$ is increased 24-48 hours after exposure.

Methods - Thirteen mild atopic asthmatic volunteers were exposed for six hours to a single exposure of air and three exposures of the combination of $400 \mathrm{ppb} \mathrm{NO}_{2}$ $+200 \mathrm{ppb} \mathrm{SO}_{2}$ in randomised order, and then challenged with increasing concentrations of Dermatophagoides pteronyssinus allergen either immediately after exposure to air, or immediately, 24 hours or 48 hours after exposure to the combination of the two pollutants, until a $20 \%$ fall in forced expiratory volume in one second $\left(\mathrm{FEV}_{1}\right)$ was recorded.
\end{abstract}

Results - Exposure to $400 \mathrm{ppb} \quad \mathrm{NO}_{2}$ $+200 \mathrm{ppb} \mathrm{SO}_{2}$ significantly decreased the dose of $D$ pteronyssinus allergen required to produce a $20 \%$ fall in $\mathrm{FEV}_{1}$ $\left(\mathbf{P D}_{20} \mathrm{FEV}_{1}\right)$ at all times after exposure when compared with air. The mean percentage changes in allergen $\mathrm{PD}_{20} \mathrm{FEV}_{1}$ immediately, 24 hours, and 48 hours after exposure to $400 \mathrm{ppb} \mathrm{NO}_{2}+200 \mathrm{ppb} \mathrm{SO}_{2}$ were $-37 \%(95 \%$ confidence intervals $(\mathrm{CI})$ -50 to -23$),-63 \%(\mathrm{CI}-75$ to -51$)$, and $-49 \%$ (CI -75 to -28.8 ), respectively, when compared with the $\mathrm{PD}_{20} \mathrm{FEV}_{1}$ after air exposure and were significant at all time points studied. The allergen PD $_{20}$ FEV $_{1}$ at 24 hours after exposure to the combination of the two pollutants was also found to be significantly lower when compared with that immediately after exposure to the two pollutants.

Department of
Asthma and Allergic Respiratory Diseases, St Bartholomew's and the Royal London School of Medicine and Dentistry, London E2 9JX, UK

C Rusznak

J L Devalia

R J Davies

Correspondence to: Professor R J Davies.

Received 9 June 1995

Returned to authors

4 August 1995

Revised version received

3 May 1996

Accepted for publication

9 May 1996

that exposure to a combination of $\mathrm{NO}_{2}$ and $\mathrm{SO}_{2}$, at concentrations which can be encountered during episodes of increased outdoor and indoor air pollution, enhances the airway response to inhaled allergen in asthmatic subjects. This effect persists over a period of 24-48 hours and is maximal 24 hours after exposure to these air pollutants.

(Thorax 1996;51:1105-1108)
Epidemiological studies have suggested that there may be a link between episodes of severe air pollution and emergency room admissions for asthma, impaired lung function, cough, and infections of the lower respiratory tract, and that the clinical effects of pollutants may occur within 1-2 days of exposure. ${ }^{1}$ Bates and colleagues analysed the daily attendances at the accident and emergency departments of nine hospitals in relation to pollution levels in Vancouver, Canada and found that, in the winter, visits for respiratory complaints in all age groups were correlated with levels of sulphur dioxide $\left(\mathrm{SO}_{2}\right){ }^{2}$ Additionally, these authors found that there was a correlation between respiratory visits and levels of nitrogen dioxide $\left(\mathrm{NO}_{2}\right)$ on the same day and 1-2 days later in patients over 60 years of age. Similarly, retrospective studies by Walters and colleagues have demonstrated that there were significant associations between the winter levels of $\mathrm{SO}_{2}$ and smoke and hospital admissions for asthma and other respiratory conditions, lagged by two days, in Birmingham, UK. ${ }^{3}$

Recent evidence suggests that exposure to pollutants may also contribute to increased airway responsiveness in atopic individuals genetically predisposed to airway disease. Tunnicliffe and colleagues ${ }^{4}$ have shown that exposure for one hour to $400 \mathrm{ppb} \mathrm{NO}_{2}$ increased airway responsiveness to inhaled allergen in atopic asthmatic subjects. Similarly, we have reported recently that exposure for six hours to a combination of $400 \mathrm{ppb} \mathrm{NO}_{2}$ and $200 \mathrm{ppb} \mathrm{SO}_{2}$, but not the individual pollutants, led to a significant decrease in the amount of Dermatophagoides pteronyssinus allergen needed to produce a $20 \%$ fall in forced expiratory volume in one second $\left(\mathrm{FEV}_{1}\right)$ in mild asthmatic patients. ${ }^{5}$ In the present study we have tested the hypothesis that pollution induced increase in airway responsiveness to inhaled allergen in atopic asthmatic patients is maximal 1-2 days after exposure to the pollutants.

\section{Methods}

SUBJECTS

Keywords: air pollutants, asthma, airway reactivity.
POWER CALCULATION

The number of subjects recruited into the study was estimated on the basis of findings from 
Table 1 Mean (SE) lung function and airway hyperresponsiveness parameters on each study day

\begin{tabular}{|c|c|c|c|c|c|c|c|c|c|c|c|c|c|c|c|c|c|c|c|c|c|c|c|}
\hline \multicolumn{5}{|c|}{$\begin{array}{l}\text { Air exposure } \\
\text { (challenge immediately after exposure) }\end{array}$} & \multicolumn{5}{|c|}{$\begin{array}{l}\mathrm{NO}_{2}+\mathrm{SO}_{2} \text { exposure } \\
\text { (challenge immediately after exposure) }\end{array}$} & \multicolumn{7}{|c|}{$\begin{array}{l}\mathrm{NO}_{2}+\mathrm{SO}_{2} \text { exposure } \\
\text { (challenge } 24 \text { hours after exposure) }\end{array}$} & \multicolumn{7}{|c|}{$\begin{array}{l}\mathrm{NO}_{2}+\mathrm{SO}_{2} \text { exposure } \\
\text { (challenge } 48 \text { hours after exposure) }\end{array}$} \\
\hline \multicolumn{2}{|c|}{ FEV } & \multicolumn{2}{|l|}{$\begin{array}{l}\text { FVC } \\
\text { (l) }\end{array}$} & \multirow[t]{2}{*}{$\begin{array}{l}P D_{20} F E V_{1} \\
(C B U)\end{array}$} & \multicolumn{2}{|l|}{$\begin{array}{l}F E V_{1} \\
\text { (l) }\end{array}$} & \multicolumn{2}{|l|}{$\begin{array}{l}\text { FVC } \\
\text { (l) }\end{array}$} & \multirow[t]{2}{*}{$\begin{array}{l}P D_{20} F E V_{1} \\
(C B U)\end{array}$} & \multicolumn{3}{|l|}{$\begin{array}{ll}F E V_{1} \\
\text { (l) }\end{array}$} & \multicolumn{3}{|l|}{$\begin{array}{l}F V C \\
\text { (l) }\end{array}$} & \multirow[t]{2}{*}{$\begin{array}{l}P D_{20} F E V_{1} \\
(C B U)\end{array}$} & \multicolumn{3}{|l|}{$\begin{array}{l}F E V_{1} \\
\text { (l) }\end{array}$} & \multicolumn{3}{|l|}{$\begin{array}{l}F V C \\
\text { (l) }\end{array}$} & \multirow[t]{2}{*}{$\begin{array}{l}P D_{20} F E V_{1} \\
(C B U)\end{array}$} \\
\hline $\begin{array}{l}\text { Pre } \\
\exp \end{array}$ & $\begin{array}{l}\text { Post } \\
\exp \end{array}$ & $\begin{array}{l}\text { Pre } \\
\text { exp }\end{array}$ & $\begin{array}{l}\text { Post } \\
\exp \end{array}$ & & $\begin{array}{l}\text { Pre } \\
\text { exp }\end{array}$ & $\begin{array}{l}\text { Post } \\
\exp \end{array}$ & $\begin{array}{l}\text { Pre } \\
\exp \end{array}$ & $\begin{array}{l}\text { Post } \\
\exp \end{array}$ & & $\begin{array}{l}\text { Pre } \\
\exp \end{array}$ & $\begin{array}{l}\text { Post } \\
\exp \end{array}$ & $\begin{array}{l}\text { Pre } \\
\text { chall }\end{array}$ & $\begin{array}{l}\text { Pre } \\
\exp \end{array}$ & $\begin{array}{l}\text { Post } \\
\exp \end{array}$ & $\begin{array}{l}\text { Pre } \\
\text { chall }\end{array}$ & & $\begin{array}{l}\text { Pre } \\
\exp \end{array}$ & $\begin{array}{l}\text { Post } \\
\exp \end{array}$ & $\begin{array}{l}\text { Pre } \\
\text { chall }\end{array}$ & $\begin{array}{l}\text { Pre } \\
\exp \end{array}$ & $\begin{array}{l}\text { Post } \\
\exp \end{array}$ & $\begin{array}{l}\text { Pre } \\
\text { chall }\end{array}$ & \\
\hline $\begin{array}{l}3.78 \\
(0.2\end{array}$ & $\begin{array}{l}3.70 \\
(0.25)\end{array}$ & $\begin{array}{l}4.83 \\
(0.27)\end{array}$ & $\begin{array}{l}4.65 \\
(0.28)\end{array}$ & 2266 & $\begin{array}{l}3.89 \\
(0.19)\end{array}$ & $\begin{array}{l}3.78 \\
(0.22)\end{array}$ & $\begin{array}{l}4.87 \\
(0.24)\end{array}$ & $\begin{array}{l}4.73 \\
(0.25)\end{array}$ & 1330 & $\begin{array}{l}3.88 \\
(0.20)\end{array}$ & $\begin{array}{l}3.70 \\
(0.24)\end{array}$ & $\begin{array}{l}3.71 \\
(0.23)\end{array}$ & $\begin{array}{l}4.87 \\
(0.25)\end{array}$ & $\begin{array}{l}4.60 \\
(0.30)\end{array}$ & $\begin{array}{l}4.75 \\
(0.26)\end{array}$ & 724 & $\begin{array}{l}3.92 \\
(0.22)\end{array}$ & $\begin{array}{l}3.78 \\
(0.82)\end{array}$ & $\begin{array}{l}3.85 \\
(0.23)\end{array}$ & $\begin{array}{l}4.79 \\
(0.24)\end{array}$ & $\begin{array}{l}4.74 \\
(0.24)\end{array}$ & $\begin{array}{l}4.80 \\
(0.25)\end{array}$ & 895 \\
\hline
\end{tabular}

$\mathrm{FEV}_{1}=$ forced expiratory volume in one second $\mathrm{FVC}=$ forced vital capacity; $\mathrm{PD}_{20} \mathrm{FEV}_{1}=$ dose of allergen required to produce a $20 \%$ fall in $\mathrm{FEV}$; exp $=$ exposure; chall $=$ challenge .

our previous study ${ }^{5}$ which showed a $60.5 \%$ reduction in the dose of $D$ pteronyssinus allergen needed to produce a $20 \%$ fall in $\mathrm{FEV}_{1}$ $\left(\mathrm{PD}_{20} \mathrm{FEV}_{1}\right)$ following exposure for six hours to a combination of $400 \mathrm{ppb} \mathrm{NO}_{2}+200 \mathrm{ppb}$ $\mathrm{SO}_{2}$ in eight asthmatic individuals. The number of subjects required to observe a difference between the response to allergen inhalation after exposure to air or a combination of $400 \mathrm{ppb} \mathrm{NO}_{2}+200 \mathrm{ppb} \mathrm{SO}_{2}$ at $\alpha=0.05$ with $80 \%$ power was calculated according to the formula:

$$
\frac{\left(\mathrm{z}_{\mathrm{a}}+\mathrm{z}_{2 \beta}\right)^{2} \sigma_{\mathrm{w}} 2}{\sigma^{2}}=9.22(\sim 10)
$$

where $z_{a}$ and $z_{2 \beta}$ are the ordinates for the normal distribution, $\sigma$ is the difference between treatments, and $\sigma_{w}$ is its standard deviation. Fourteen volunteers were recruited to allow for withdrawals.

\section{STUDY DESIGN}

On the first day of the study each volunteer was skin prick tested and his/her lung function evaluated by measuring forced vital capacity (FVC) and $\mathrm{FEV}_{1}$. This was followed by allergen inhalation provocation testing as described previously. ${ }^{5}$ On subsequent visits, which were at least two weeks apart, each volunteer underwent spirometric testing at the beginning of each visit and was then subjected to one of the following four experimental protocols in single blind randomised order: (1) exposure for six hours to air followed by spirometric testing immediately and then 10 minutes after exposure, followed by allergen challenge with $D$ pteronyssinus allergen; (2) exposure for six hours to $400 \mathrm{ppb} \mathrm{NO}_{2}+200 \mathrm{ppb} \mathrm{SO}_{2}$ followed by spirometric testing immediately and then 10 minutes after exposure, followed by allergen challenge as above (a sequence similar to that following exposure to air); (3) exposure for six hours to $400 \mathrm{ppb} \mathrm{NO}+200 \mathrm{ppb} \mathrm{SO}_{2}$ followed by spirometric testing immediately and then 24 hours after exposure, followed by allergen challenge as above; and (4) exposure for six hours to $400 \mathrm{ppb} \mathrm{NO}+200 \mathrm{ppb} \mathrm{SO}_{2}$ followed by spirometric testing immediately and then 48 hours after exposure, followed by allergen challenge as above.

In order to minimise any variations in lung function as a result of circadian rhythms, all study exposures, spirometric measurements, and allergen challenges were performed at the same time on each study day for each individual. All exposures were carried out in a modified controlled environmental chamber that we have described previously. ${ }^{5}$

\section{STATISTICAL ANALYSIS}

All spirometric data were analysed by an individual blinded to the study protocol. All data were tested for normal distribution prior to further evaluation. Differences in the $\mathrm{FEV}_{1}$ and FVC before exposure to air or the pollutant mixture and before allergen challenge were compared by Wilcoxon's non-parametric test. $\mathrm{PD}_{20} \mathrm{FEV}_{1}$ values were $\log$ transformed prior to analysis by two way analysis of variance (ANOVA) and then compared by the Student's $t$ test. Values of $\mathrm{p}<0.05$ were considered to be significant.

A comparison was also made between the allergen $\mathrm{PD}_{20} \mathrm{FEV}_{1}$ values after exposure to air and the allergen $\mathrm{PD}_{20} \mathrm{FEV}_{1}$ values immediately, 24 hours, and 48 hours after exposure to $400 \mathrm{ppb} \mathrm{NO}_{2}$ and $200 \mathrm{ppb} \mathrm{SO}$ and expressed as a percentage change with $95 \%$ confidence intervals.

\section{Results}

Thirteen volunteers (10 men) of mean (SE) age 28.1 (1.9) years (range 21-39) completed the study. Their mean (SE) baseline $\mathrm{FEV}_{1}$ values were $3.77(0.20) 1$ (93.3 (2.7)\% predicted) and FVC values were $4.74(0.25) 1$ (100.2 (2.4)\% predicted). The predicted lung function for each individual was determined using a computer software package based on tables constructed by a working party on standardised lung function testing. ${ }^{6}$ Table 1 shows the effect of exposure for six hours to either air or a combination of $400 \mathrm{ppb} \mathrm{NO}_{2}$ and $200 \mathrm{ppb}$ $\mathrm{SO}_{2}$ on $\mathrm{FEV}_{1}$ and FVC measurements of the asthmatic volunteers at the different time points studied.

Analysis of the percentage changes in $\mathrm{FEV}_{1}$ measured prior to any exposure and before allergen challenge immediately after exposure to air or immediately, 24 hours, or 48 hours after exposure to the pollutant gases showed that, although there was a slight decrease in the $\mathrm{FEV}_{1}$ at each time point following exposure to the pollutant gas mixture, this was not significantly different when compared with exposure to air. Similarly, analysis of changes in FVC showed that the slight decrease in this measurement noted immediately and 24 hours after exposure to the combination of the two pollutants was not significant when compared with exposure to air. In contrast, there was a slight but significant $(p<0.05)$ increase in FVC 


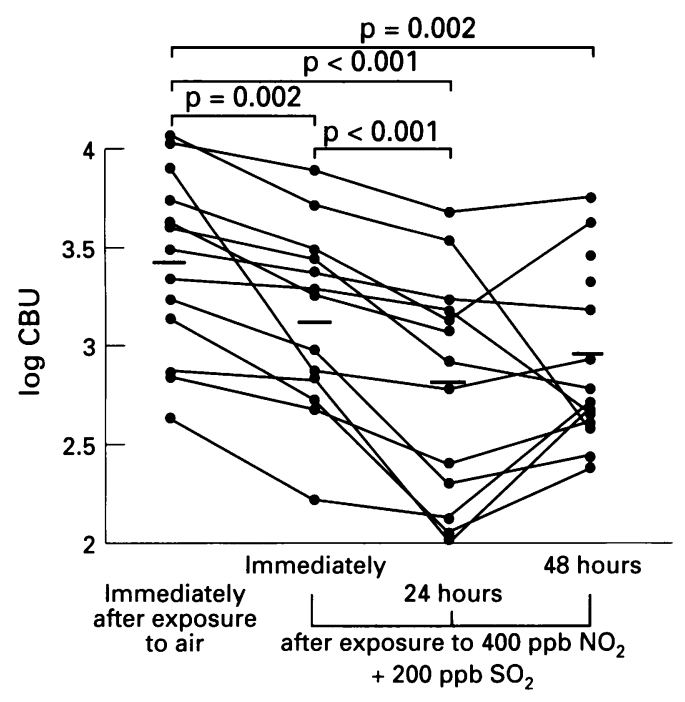

Figure 1 Effect of six hours of exposure to $400 \mathrm{ppb}$ $\mathrm{NO}_{2}+200 \mathrm{ppbSO}$ on the dose of inhaled allergen required to decrease the $F E V_{1}$ by $20 \%$ in mild asthmatic volunteers. The level of significance was determined after log transformation of the data $(C B U=$ dose of inhaled allergen expressed as cummulative breath units). Bars represent geometric means.

48 hours after exposure to the combination of $400 \mathrm{ppb} \mathrm{NO}_{2}+200 \mathrm{ppb} \mathrm{SO} \mathrm{SO}_{2}$ when compared with exposure to air.

Analysis of the results for $D$ pteronyssinus allergen $\mathrm{PD}_{20} \mathrm{FEV}_{1}$ indicated that prior exposure to the combination of $400 \mathrm{ppb} \mathrm{NO}_{2}$ $+200 \mathrm{ppb} \mathrm{SO}_{2}$ significantly decreased the $\mathrm{PD}_{20} \mathrm{FEV}_{1}$ at all time points investigated when compared with prior exposure to air for six hours. Analysis of the $D$ pteronyssinus allergen $\mathrm{PD}_{20} \mathrm{FEV}_{1}$ noted at different time points after exposure to the combination of $400 \mathrm{ppb}$ $\mathrm{NO}_{2}+200 \mathrm{ppb} \mathrm{SO}$ indicated that this was decreased by $37 \%$ ( $95 \%$ CI -50 to -23$)$ immediately after exposure, $-63 \%(95 \%$ CI -75 to -51$) 24$ hours after exposure, and $-49 \%$ (95\% CI -75 to -28.8$) 48$ hours after exposure to the pollutants compared with exposure to air. The decrease in $\mathrm{PD}_{20} \mathrm{FEV}_{1}$ was significant at 24 hours $(\mathrm{p}<0.001)$ but not at 48 hours after exposure to the combination of the two pollutants when compared with that immediately after exposure to the combination of the pollutants (fig 1).

\section{Discussion}

In this study we have confirmed the findings of our previous study that exposure of mild atopic asthmatic subjects for six hours to a combination of $400 \mathrm{ppb} \mathrm{NO}$ and $200 \mathrm{ppb} \mathrm{SO}_{2}$ leads to an increase in the airway responsiveness of these individuals to inhaled allergen without any significant detrimental effects on lung function. Furthermore, these studies have shown that the enhancing effect of the two pollutants on airway responsiveness persists over a period of 48 hours and is maximal 24 hours after exposure. The limitation of this preliminary study, however, is that allergen challenge was not carried out in each individual additionally at 24 hours and 48 hours after exposure to air, and therefore strict comparisons could not be made between the effects of prior exposure to air or the pollutant gas mixture at these times. This discrepancy in the study design was a matter of necessity rather than choice, since it would have meant that the volunteers would need to undergo a total of 11 visits instead of the minimum seven necessary to complete the study, which most of the volunteers declined to make.

To our knowledge, this is the first report of a time lagged effect of acute inhalation of atmospheric pollutants, in a laboratory setting, on human bronchial reactivity to allergen. $\mathrm{Al}$ though this was a randomised single blind study in that the investigator, but not the volunteer, was aware of the nature of the study gases on different exposure days, assessment and calculation of all results (spirometric and allergen $\mathrm{PD}_{20} \mathrm{FEV}_{1}$ values) were performed by an investigator blinded to the study protocol. The six hour exposure period employed in this study is similar to that used in previous studies in our laboratory and is representative of exposure experienced by taxi and bus drivers, traffic wardens, couriers, and road maintenance workers during episodes of pollution. Indeed, studies of households with gas cooking appliances have suggested that exposure to high levels of $\mathrm{NO}_{2}$ may occur over prolonged periods in the kitchen/indoors. ${ }^{78}$

Previous epidemiological studies have suggested that there may be a time lagged association between increased levels of $\mathrm{NO}_{2}$ and $\mathrm{SO}_{2}$ and impaired lung function, respiratory symptoms, and hospital emergency room visits maximal 1-2 days after exposure. ${ }^{1}$ Controlled exposure chamber studies investigating the putative mechanisms underlying airway disease induced by exposure to $\mathrm{NO}_{2}$ /ozone have suggested that the time lagged effects of these pollutants may be a consequence of physiological and biochemical effects which become manifest 18-24 hours after exposure. Sandström and colleagues ${ }^{9}$ have shown that exposure of healthy non-smoking individuals to $\mathrm{NO}_{2}$ increased the numbers of lymphocytes, lysozyme positive alveolar macrophages, and mast cells in bronchoalveolar lavage fluid 24 hours after exposure, and Rasmussen and colleagues ${ }^{10}$ have shown that exposure to $\mathrm{NO}_{2}$ decreased alveolar permeability and serum glutathione peroxidase activity 24 hours after exposure in healthy volunteers. Similarly, studies of ozone inhalation have shown that this air pollutant also increases airway epithelial damage and the inflammatory response in the airways 18-24 hours after exposure, indicated by leakage of lactate dehydrogenase and total protein, and significant increases in the numbers of neutrophils and concentrations of $\alpha_{1}-$ antitrypsin, fibronectin, interleukin 8 , and granulocyte macrophage-colony stimulating factor (GM-CSF) in proximal airway lavage and bronchoalveolar lavage fluids of healthy volunteers. ${ }^{11}$

In conclusion, our results suggest that exposure of mild asthmatic subjects to a combination of $400 \mathrm{ppb} \mathrm{NO}$ and $200 \mathrm{ppb} \mathrm{SO}_{2}$ can lead to an increase in the airway response to 
inhaled allergen, not only immediately after exposure but also up to 48 hours later.

The authors thank the British Lung Foundation, the National The authors thank the British Lung Foundation, the National Asthma Campaign (UK), and the Joint Research Board of St Bartholomew's Hospital, London (UK) for financial support, and Ms Janice Thomas (Statistician, St Bartholomew's Hos-
pital) for her help in statistical analysis of the data obtained from these studies.

1 Devalia JL, Rusznak C, Davies RJ. Air pollution in the 1990s - cause of increased respiratory disease? Respir Med 1994;88:241-4.

2 Bates DV, Baker-Anderson M, Sizto R. Asthma attack periodicity: a study of hospital emergency visits in Vancouver. Environ Res 1990;51:51-70.

3 Walters S, Griffiths RK, Ayres JG. Temporal association between hospital admissions for asthma in Birmingham and ambient levels of sulphur dioxide and smoke. Thorax and ambient levels

4 Tunnicliffe WS, Burge PS, Ayres JG. Effect of domestic concentrations of nitrogen dioxide on airway responses to inhaled allergen in asthmatic patients. Lancet 1994;344: $1733-6$
5 Devalia JL, Rusznak C, Herdman MJ, Trigg CJ, Tarraf H, Davies RJ. Effect of nitrogen dioxide and sulphur dioxide
on the airway response of mild asthmatic patients to on the airway response of mild asthmatic pat
allergen inhalation. Lancet 1994;344:1668-71.

6 Quanjer PhH. Standardized lung function testing. Report working party for the European Community for Steel and Coal. Bull Eur Physiopathol

7 Koo LC, Ho JH, Ho CY, Matsuki H, Shimizu H, Mori $\mathrm{T}$, et al. Personal exposure to nitrogen dioxide and its association with respiratory illness in Hong Kong. Am Rev Respir Dis 1990;141:1119-26.

8 Jarvis D, Chinn S, Luczynska C, Burney P. Association of respiratory symptoms and lung function in young adults with use of domestic appliances. Lancet 1996;347:426-31.

9 Sandström T, Sternberg N, Eklund A, Ledin M-C, Bjemer L, Kolmodin-Hedman $B$, et al Inflammatory cell response $\mathrm{L}$, Kolmodin-Hedman $\mathrm{B}$, et al. Inflammatory cell response in bronchoalveolar lavage fluid after nitrogen dioxide exposure of healthy subjects: a dose-response study. Eur
Respir f 1991;3:332-9. Respir f 1991;3:332-9.

Rasmussen TR, Kjaergaard SK, Tarp U, Pederson OF Delayed effects of $\mathrm{NO}_{2}$ exposure on alveolar permeability and glutathione peroxidase in healthy humans. $A m$ Rev Respir Dis 1992;146:654-9.

11 Aris RM, Christian D, Hearne PQ, Kerr K, Finkbeiner WE, Balmes JR. Ozone-induced airway inflammation in human subjects as determined by airway lavage and biopsy. $A m$ Rev Respir Dis 1993;148:1363-72. 